\title{
Effects of increasing water temperature and decreasing water oxygen concentration on enzyme activity in developing carp embryos (Cyprinus carpio)
}

\author{
Oleksandr M. Vodianitskyi, Oleksandr S. Potrokhov, Oleg G. Zinkovskyi, Yurii M. \\ Khudiiash, Mykola V. Prychepa
}

Received - 03 April 2019/Accepted - 02 February 2021. Published online: 31 March 2021; @Inland Fisheries Institute in Olsztyn, Poland Citation: Vodianitskyi, O.M., Potrokhov, O.S., Zinkovskyi, O.G., Khudiiash, Y.M., Prychepa M.V. (2021). Effects of increasing water temperature and decreasing water oxygen concentration on enzyme activity in developing carp embryos (Cyprinus carpio). Fisheries \& Aquatic Life 29(1), 35-44

\begin{abstract}
Climate change inevitably leads to increased water temperatures, which is especially important in natural spawning grounds during mass fish spawning. Studies were performed to determine the effects of increased water temperature with decreased water oxygen concentrations on the activity of $\mathrm{Na}^{+} / \mathrm{K}^{+}$ATPase, lactate dehydrogenase (LDH), and succinate dehydrogenase in developing carp embryos. The activities of ATP and LDH decreased several times when water temperature increased from 24 to $31^{\circ} \mathrm{C}$. LDH activity increased up to 1.9 times. Thus, the fish embryos used glycolysis to a greater extent, the level of their aerobic respiration decreased, and mineral exchange with the environment was weakened. These phenomena could have disrupted embryonic development and decreased fish embryo viability.
\end{abstract}

Keywords: fish, $\mathrm{Na}^{+} / \mathrm{K}^{+}$ATPase, lactate dehydrogenase, succinate dehydrogenase, sensitivity, adaptation

\footnotetext{
O.M. Vodianitskyi, O.S. Potrokhov [" $\left.\Xi^{\circ}\right]$, O.G. Zinkovskyi, Yu.M. Khudiiash, M.V. Prychepa Department of Biology of Fish Reproduction, Institute of Hydrobiology, National Academy of Science of Ukraine, Geroyiv Stalingrada prospect, 12, Kyiv - 210, 04210-UA, Ukraine E-mail:: Oleksandr S. Potrokhov, alport@bigmir.net
}

\section{Introduction}

Water temperature and oxygen concentration greatly affect all levels of hydrobiont structural organization from cells to the organism (Nilsson and Renshaw 2004, Sollid et al. 2005, van der Meer et al. 2005). Even insignificant fluctuations in these environmental parameters can impact the physiological states of fishes (Herzig and Winkler 1986, Konstantinov and Zdanovich 1986, Schneider et al. 2002, Das et al. 2006, Eme et al. 2015, Richards et al. 2009, Anderson 2012). Since there is a relationship between metabolic and enzymatic activities, it is definitely possible to characterize the status of fishes using these molecular biomarkers (D'Amico et al. 2002). The main molecular metabolism biomarkers include the activities of $\mathrm{Na}^{+} / \mathrm{K}^{+}$ATPase, $\mathrm{Ca}^{2+}, \mathrm{Mg}^{2+}$-ATPases, and total ATPase, lactate dehydrogenase $(\mathrm{LDH})$, and succinate dehydrogenase (SDH) (Dahlhoff 2004, Menzorova and Rasskazov 2007).

Increases in temperature within the tolerated range leads to increased intensity in the body's metabolism, while decreases in it leads to decreased metabolism (Hochachka and Somero 2002). Meanwhile, the main metabolic processes in the body 
must be maintained at certain levels. These can change only within rather narrow limits, otherwise homeostasis is violated, which leads to organism death (Love 1976). It should be emphasized that for normal metabolic processes, the degree of temperature change and the rate of change are both important. Sharp temperature decreases can lead to decelerated metabolic processes that can no longer sustain normal life processes, while significant temperature increases can cause such an acceleration in the intensity of metabolic processes that it is difficult or impossible to provide the oxygen they require (Via et al. 1994, Gracey et al. 2011). Therefore, in poikilothermic animals, the control mechanisms of the intensity of metabolic processes, are, first of all, due to enzymatic regulation. The most notable changes in fish enzymatic activity are observed in the embryonic and early post-embryonic stages of development. They are observed under optimum conditions due to the presence of critical stages of the development of embryos and larvae of fish, and for the actions of factors of different nature (Vovk 1974).

Changes in the functioning of cell membranes might play an important role in temperature adaptation (Zaprudnova 2001). The role of $\mathrm{Na}^{+} / \mathrm{K}^{+}$ATPase is key not only in supporting the structural integrity of membranes, but also in ensuring their functional status, primarily ion exchange (Zaprudnova 2003). This enzyme is involved in osmotic and ionic regulation processes, and it provides active transport. It is built into the outer plasma membrane of cells and provides for the transfer of $\mathrm{Na}^{+}$and $\mathrm{K}^{+}$ions against their concentration gradient. Additionally, $\mathrm{Na}^{+} / \mathrm{K}^{+}$ ATPase regulates the transfer of various metabolites, including sugars and amino acids, across cell membranes (Boiko et al. 2002). The $\mathrm{Na}^{+} / \mathrm{K}^{+}$ATPase of cell membranes is one of the first enzymes that ensures primary reactions to the action of factors and triggers the mechanisms for the formation of long-term adaptation.

The most important factor determining normal body functioning and its ability to adapt to changing environmental conditions is the level of energy metabolism. The fundamental process of generating ATP energy in higher animals is aerobic. In the Krebs cycle, SDH catalyzes the reverse oxidation of succinic acid to fumaric acid. The activity of dehydrogenases can be used to diagnose the body condition in the presence of diseases or under adverse conditions (Ahmad and Hasnain 2005, Abrosimova and Abrosimova 2012). When environmental conditions change, mainly when the concentration of dissolved oxygen in water decreases, glycolysis processes are enhanced. The change in the ratio of SDH/LDH toward increased LDH activity and decreased SDH activity indicate the predominance of anaerobic processes and the inhibition of redox. When water temperatures decrease below the optimum, metabolic processes slow down considerably and glycolytic energy is generated, in particular, thanks to increased LDH activity. This enzyme is key in glycolysis, and its activity is used to determine the level of anaerobic metabolism in bodies (Ahmad and Hasnain 2005, Abrosimova and Abrosimova 2012).

The purpose of our work was to establish which biochemical changes in enzyme activity occurred in carp embryos and larvae in natural spawning grounds in response to atypical increases in water temperature and to fluctuations in water temperature during the day.

\section{Material and Methods}

The investigations were conducted in July 2018, at the Bila Tserkva Experimental Station of the Institute of Hydrobiology of the National Academy of Sciences of Ukraine located in Oleksandriya Park (in the town of Bila Tserkva, Ukraine) (4947’56"N 3006’55"E) (Fig. 1). We selected three ponds with an area of 0.04 ha and an average depth of $1.2 \mathrm{~m}$. They differed in temperature and oxygen regimes because of their locations and the degree to which they were shaded by trees. This was especially important because it is these indicators that are the most volatile under climate change. The water temperature was measured with a mercury thermometer during the day at 08:00, 12:00, and 19:00. Dissolved oxygen content was measured at 04:00 with the Winkler method. All of 


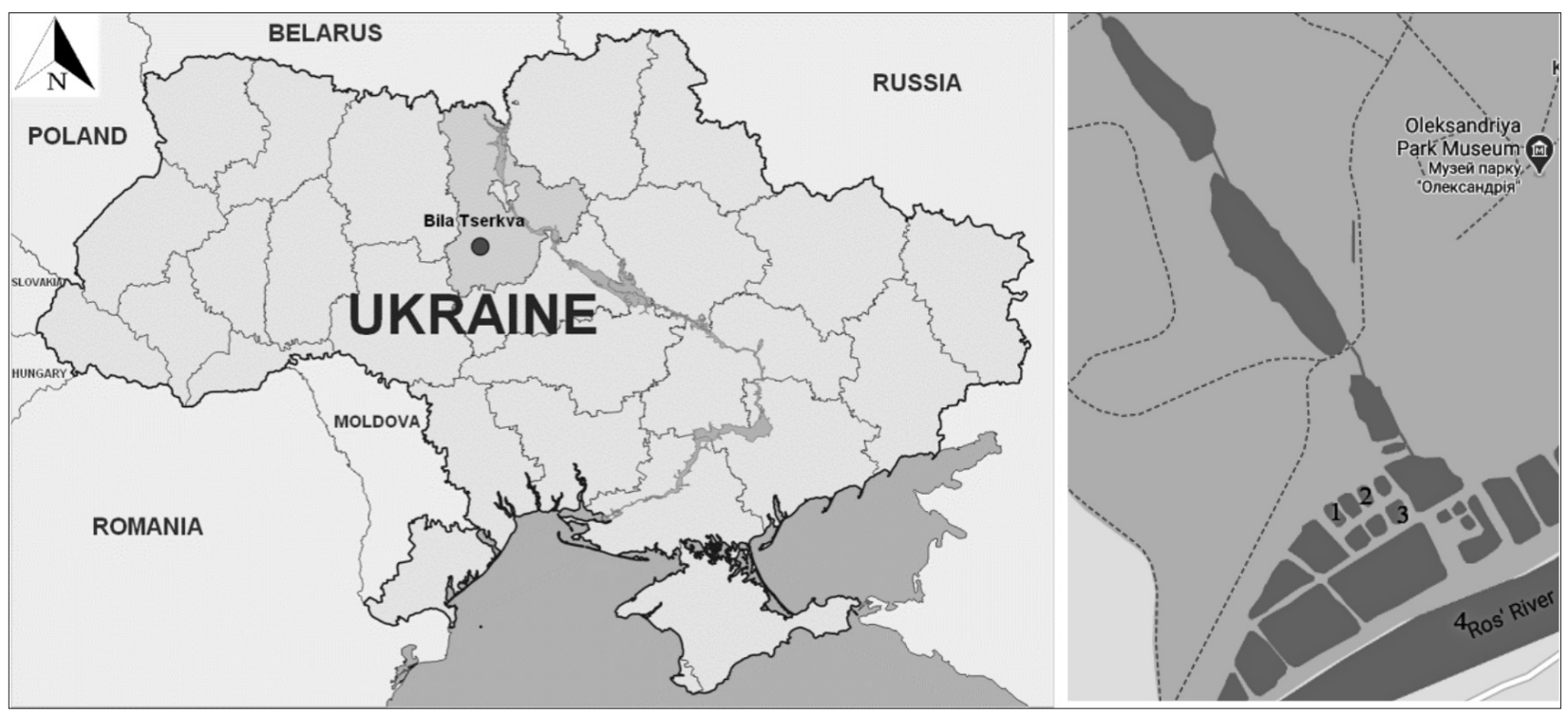

Figure 1. Map of the ponds in Oleksandriya Dendrological Park. 1-3 - experimental ponds, 4 - small storage reservoir (Ros River).

the ponds investigated were filled with water from a small storage reservoir on the Ros River. The hydrochemical parameters of the water from the Ros River and in the ponds studied practically did not differ (Ros River / ponds): $\mathrm{pH}$ - 7.9-8.2 / 8.2-8.3; hardness - 5.9-6.2 / 6.1-6.3 $\mathrm{mg}^{\text {-eq }} \mathrm{l}^{-1}$; $\mathrm{Ca}^{2+}$ ions $57.0-60.4 / 57.8-66.1 \mathrm{mg} \mathrm{l}^{-1} ; \mathrm{Mg}^{2+}-26.5-34.8 /$ 34.0-35.2 $\mathrm{mg} \mathrm{l}^{-1}$; $\mathrm{Cl}^{-}-32.1-38.7 / 30.1-39.2 \mathrm{mg} \mathrm{l}^{-1}$; $\mathrm{NH}_{4}+-0.10-0.23 / 0.28-0.51 \mathrm{mg} \mathrm{N} \mathrm{l}{ }^{-1} ; \mathrm{NO}_{2}^{-}{ }^{-}$ $0.03-0.08$ / 0.06-0.11 $\mathrm{mg} \mathrm{N} \mathrm{l}^{-1} ; \mathrm{NO}_{3}^{-}-0.44-0.96 /$ 0.80-1.2 mg N l-1 $\mathrm{PO}_{4}{ }^{3-}-0.072-0.180 /$ 0.054-0.062 $\mathrm{mg} \mathrm{P} \mathrm{l}^{-1}$; permanganate oxidizability 7.6-9.2 / 8.0-9.1 mg O l${ }^{-1}$; dichromate oxidizability - 19.6-26.8 / 18.5-19.1 $\mathrm{mg} \mathrm{O} \mathrm{l}^{-1}$.

Artificially fertilized carp eggs were placed in containers (surface $=169 \mathrm{~cm}^{2}$ ) in each pond. The containers were made of metal wire, covered with 1 $\mathrm{mm}$ mesh. Five series of experiments were conducted in triplicate with eggs from different females for each pond in May. Eggs from each female were placed in three containers for sampling at each stage of embryo development. The average number of eggs in each netting container was 100-150. For comparison, control groups of eggs were kept under controlled conditions (Ros River) at a fairly constant water temperature and oxygen concentration.
During the experiment with the carp eggs, the average daily water temperature differences in the ponds were between $0.5-1.8^{\circ} \mathrm{C}$ (Fig. 2), while in the morning and evening hours the temperature differences increased to $1.0-2.4^{\circ} \mathrm{C}$. During the studies in May, the water temperatures in the ponds fluctuated between 19.3 and $29.4^{\circ} \mathrm{C}$. In the control groups kept under controlled conditions, the water temperature was $22.0-22.5^{\circ} \mathrm{C}$. The average temperature of the water in the morning was as follows: in pond No. 1 $20.6^{\circ} \mathrm{C}$; No. $2-21.1^{\circ} \mathrm{C}$; No. $3-20.2^{\circ} \mathrm{C}$; and in the evening: No $1-26.3^{\circ} \mathrm{C}$; No $2-26.4^{\circ} \mathrm{C}$; No $3-$ $24.7^{\circ} \mathrm{C}$. In the predawn hours, the dissolved oxygen concentration in the water decreased at elevated temperatures. A significant decrease in the oxygen content of the water to $2.5-3.6 \mathrm{mg} \times \mathrm{l}^{-1}$ was noted in the warmest pond $\left(19.6-24.1^{\circ} \mathrm{C}\right)$ for $4 \mathrm{~h}$ in the morning. In the pond with an average temperature $\left(19.3-23.3^{\circ} \mathrm{C}\right)$, the oxygen content decreased to $2.7-4.1 \mathrm{mg} \mathrm{l}^{-1}$. In the moderately heated pond $\left(18.5-23.7^{\circ} \mathrm{C}\right)$, the oxygen content did not decrease below 4.5-5.6 $\mathrm{mg} \mathrm{l}^{-1}$. In the control groups kept under controlled conditions, the water oxygen content was between 7.5 and $10.2 \mathrm{mg} \mathrm{l}^{-1}$.

When the eggs reached the late gastrula developmental stage, the embryos in steps E5 (organogenesis) and E6 (active movement) were 

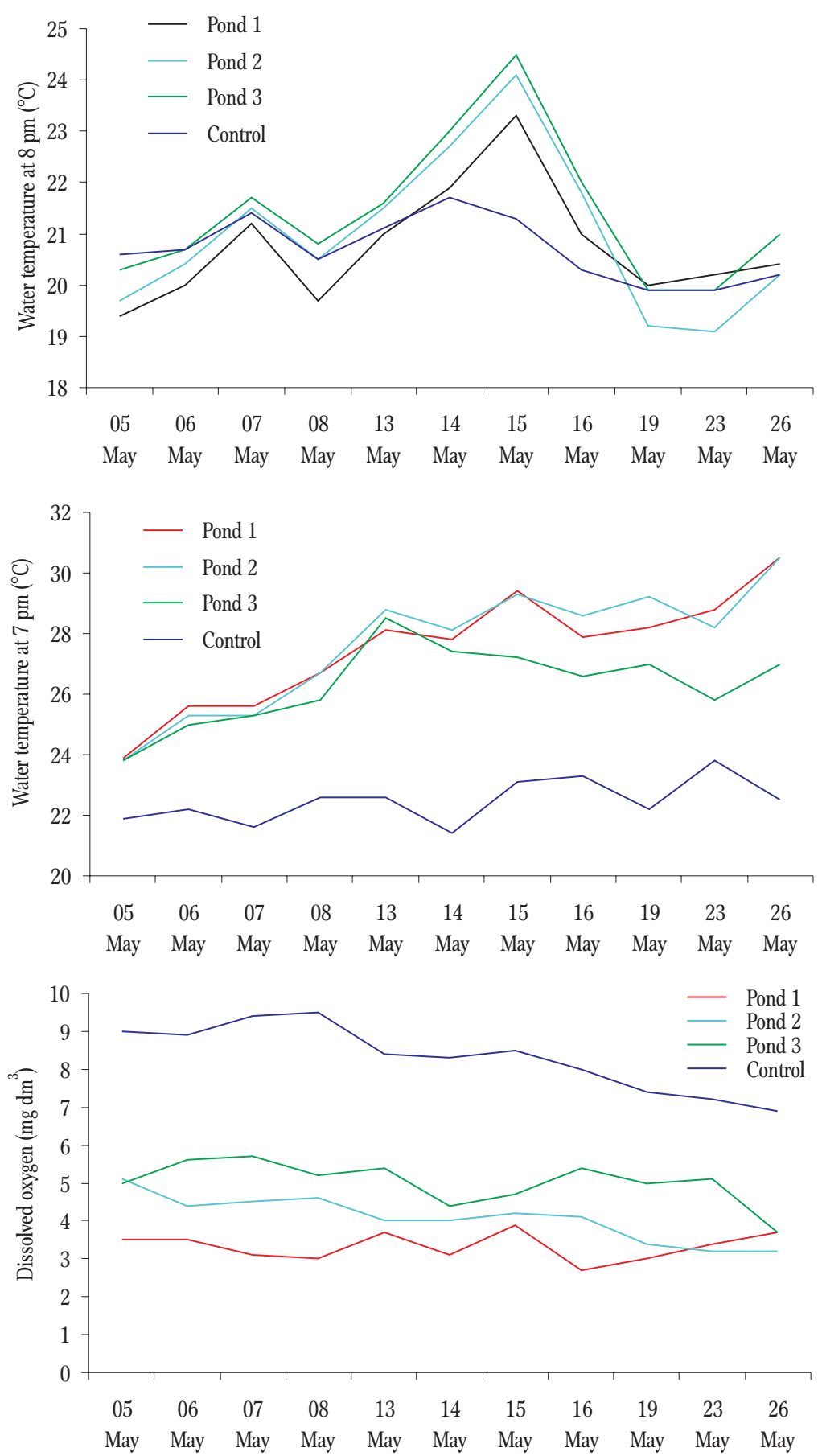

Figure 2. Water temperature and dissolved oxygen in the ponds studied during monitoring of carp egg development.

collected and frozen in a freezer at $-18^{\circ} \mathrm{C}$. The samples collected were packed in a portable freezer bag with cold elements and transported to the laboratory for further biochemical studies. The dependence of enzyme activity on water temperature was established based on specific water temperatures during sampling regardless of the pond in which the embryos were located.

All live eggs from each container (up to $200 \mathrm{mg}$ ) were homogenized in $0.2 \mathrm{M} \mathrm{KCl}(5 \mathrm{~mL})$ in a 
homogenizer. Then the homogenate was centrifuged at $3000 \mathrm{rpm}$ for $15 \mathrm{~min}$. The activity of $\mathrm{Na}^{+} / \mathrm{K}^{+}$ ATPase was measured by increasing the content of inorganic phosphorus (Prohorova 1982). The $2 \mathrm{~mL}$ reaction mixture consisted of Tris $\mathrm{HCl}(2.5 \mathrm{mg}), \mathrm{NaCl}$ (11 mg), $\mathrm{KCl}$ (3 mg), $\mathrm{MgCl}_{2} \times 6 \mathrm{H}_{2} \mathrm{O}$ (2 mg), ATP (2.5 $\mathrm{mg})$, and enzyme extract $(0.5 \mathrm{~mL})$. The reaction mixture was incubated for $60 \mathrm{~min}$ at $25^{\circ} \mathrm{C}$. The reaction was stopped by the addition of $1 \mathrm{ml}$ of $10 \%$ TCA. Subsequently, $0.1 \mathrm{ml}$ of the extract obtained and 0.4 $\mathrm{ml}$ of $20 \%$ ammonium molybdate in $8 \mathrm{~N}$ sulfuric acid was added to $3 \mathrm{ml}$ of ethyl alcohol. Absorbance was measured at $390 \mathrm{~nm}$ with a spectrophotometer.

LDH activity was determined using the method by Prohorova (1982); $3 \mathrm{ml}$ of phosphate buffer (pH 7.5) with pyruvate $(0.06 \mathrm{mg})$ and $\mathrm{NADH}(0.3 \mathrm{mg})$ were added $0.1 \mathrm{ml}$ of the enzyme extract. Absorbance was measured at $340 \mathrm{~nm}$ with a spectrophotometer every $30 \mathrm{~s}$ for $3 \mathrm{~min}$. SDH activity was determined with the ferricyanide method (Asatiani 1965); $0.5 \mathrm{ml}$ of enzyme extract was added to $1.4 \mathrm{ml}$ of phosphate buffer (pH 7.8) with succinic acid (1 mg), EDTA (0.005 mg), and sodium aside $(1.0 \mathrm{mg})$. The reaction mixture was incubated for $15 \mathrm{~min}$ at $25^{\circ} \mathrm{C}$. Then $0.1 \mathrm{mg}$ of $25 \mathrm{mM}$ potassium ferricyanide was added and the reaction mixture was incubated for $15 \mathrm{~min}$ at $25^{\circ} \mathrm{C}$. The reaction was stopped by the addition of $2 \mathrm{ml}$ of $20 \%$ TCA. Absorbance was measured at $420 \mathrm{~nm}$ with a spectrophotometer. The activity of enzymes was calculated per mg of protein in the sample. The protein content was determined using the Lowry method (Lowry et al. 1951).

The significance of differences among the mean values of the groups was determined with the T-criterion of Student's probability level $(\mathrm{P}<0.05)$. The statistical data was processed with Statistica 5.5. All bioethical norms were observed throughout the experiment.

\section{Results}

Studies have shown that an increase in water temperature and, accordingly, a decrease in oxygen concentration significantly change the activity of metabolic reactions in carp embryos. It was found that at embryo in organogenesis step, the activity of $\mathrm{Na}^{+} / \mathrm{K}^{+}$ ATPase increased at a temperature of $22.3^{\circ} \mathrm{C}$ by 4.2-7.2 times $(\mathrm{P}<0.01)$ compared to that at a temperature of $20.0-21.7^{\circ} \mathrm{C}$ (Fig. 3). With a further increase in temperature to $25.4-27.8^{\circ} \mathrm{C}$, the activity of
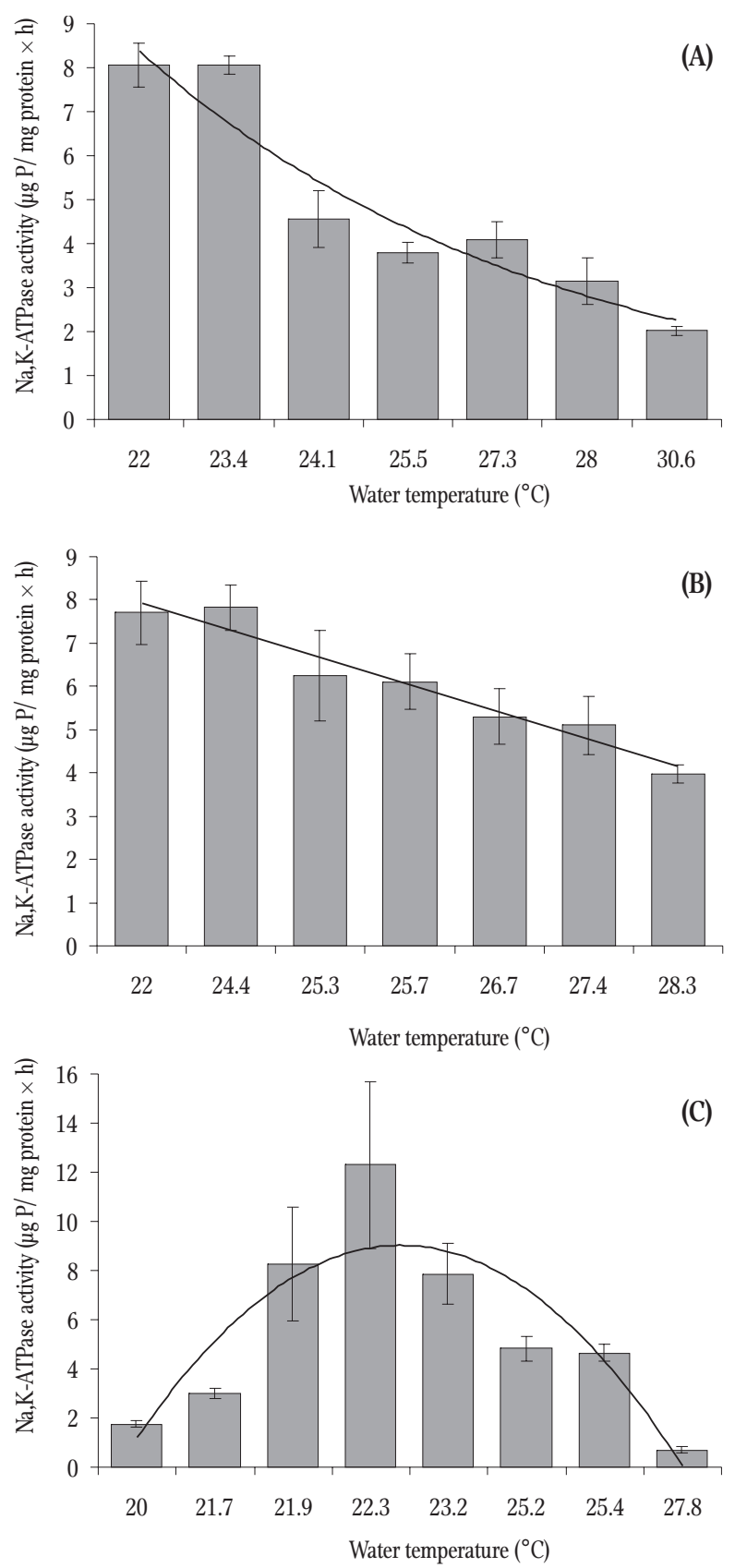

Figure 3. Changes in $\mathrm{Na}^{+} / \mathrm{K}^{+}$ATPase activity $\left(\mu \mathrm{g} \mathrm{P} \mathrm{h}^{-1} \mathrm{mg}\right.$ protein $^{-1}$ ) in carp embryos influenced by water temperature. A - embryo in organogenesis step, B - embryo in eye pigmentation step, $\mathrm{C}-$ embryo in hatching step. Data are mean $\pm \mathrm{SE}, \mathrm{n}=45$. 
the enzyme gradually decreased significantly $(\mathrm{P}<0.01)$.

At the embryo in eye pigmentation step, the $\mathrm{Na}^{+} / \mathrm{K}^{+}$ATPase activity was the highest at a temperature of $22.0-24.0^{\circ} \mathrm{C}$. As the temperature increased to $25.0-27.4^{\circ} \mathrm{C}$, the activity of this enzyme decreased and reached a significant decrease at $28.0^{\circ} \mathrm{C}$ $(\mathrm{P}<0.01)$. The temperature of $22.0-24.0^{\circ} \mathrm{C}$ was the optimal temperature regime for embryonic development in this species in natural water bodies. At the embryo in hatching step, a similar decrease in the activity of $\mathrm{Na}^{+}, \mathrm{K}^{+}$-ATPase was determined as for the previous stage of development $(\mathrm{P}<0.01)$.

An inverse relationship between SDH activity and ambient temperature was noted at all stages of carp development. SDH activity decreased with increasing temperature beyond the optimum for this species (Fig. 4). Maximum enzyme activity (6.14-6.38 nmol mg protein $\times \mathrm{min}^{-1}$ ) was recorded at the optic cup stage at the optimum water temperature $\left(21.0-24.4^{\circ} \mathrm{C}\right)$. Minimum SDH activity (1.06 nmol min $^{-1} \mathrm{mg}_{\text {protein }}{ }^{-1}$ ) was recorded at a temperature of $30.8^{\circ} \mathrm{C}$, which was six times $(\mathrm{P}<0.001)$ less than that at $21^{\circ} \mathrm{C}$. We observed similar patterns in subsequent stages of carp development, and from a temperature of $28^{\circ} \mathrm{C}$ the decrease in $\mathrm{SDH}$ activity was significant $(\mathrm{P}<0.01)$.

LDH activity clearly reflected changes in environmental conditions during carp embryonic development, primarily decreased water oxygen concentration. A direct relationship between enzyme activity and water temperature was noted at the end of the gastrula stage (Fig. 5). As the temperature increased above the optimum to $25.5-30.5^{\circ} \mathrm{C}, \mathrm{LDH}$ activity increased 1.5-2.0 times $(\mathrm{P}<0.01)$ indicating increased glycolysis processes. At the next stage of development minimum $\mathrm{LDH}$ activity was noted at a temperature of $22^{\circ} \mathrm{C}$. The value of this indicator increased significantly when the temperature increased to $26^{\circ} \mathrm{C}$. Enzyme activity began to decrease with a further increase in temperature to $28.5^{\circ} \mathrm{C}$ when it was $30 \%$ less than it was at $26^{\circ} \mathrm{C}$.

Anaerobic respiration was critical during the embryo in hatching step just before hatching and when the water was oxygenated. This was evidenced by the
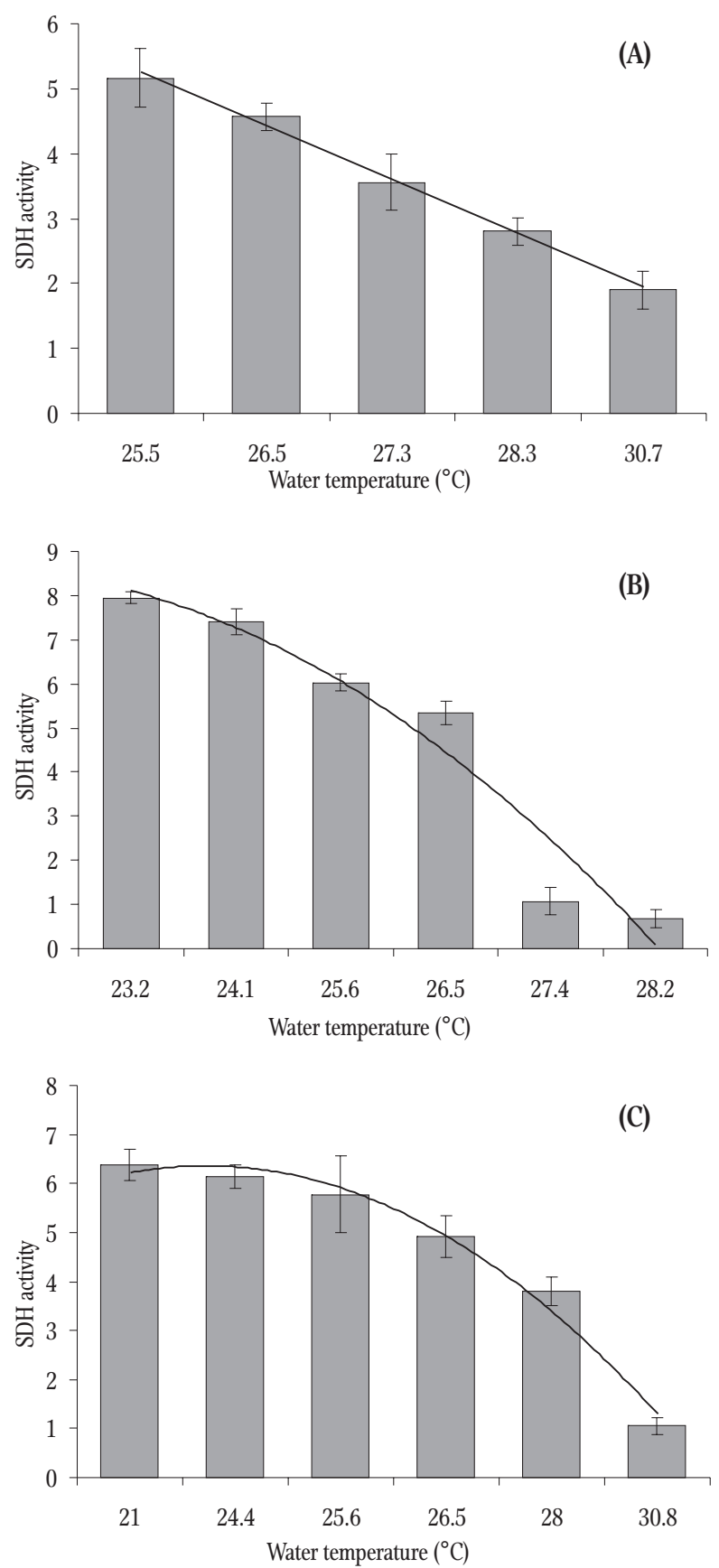

Figure 4. Changes in SDH activity (nmol $\mathrm{min}^{-1} \mathrm{mg}$ of total protein $^{-1}$ ) in carp eggs influenced by water temperature. Data are mean \pm SE, $n=45$.

increased activity of the enzyme even in the optimal temperature range and the sufficient oxygen saturation of the water. Maximum values were recorded at a water temperature of $22^{\circ} \mathrm{C}(7.12 \mathrm{nmol} \mathrm{NADH}$ $\mathrm{min}^{-1} \mathrm{mg}$ protein). LDH activity gradually decreased to $5.24 \mathrm{nmol} \mathrm{NADH} \min ^{-1} \mathrm{mg}$ protein $(\mathrm{P}<0.05)$ as 

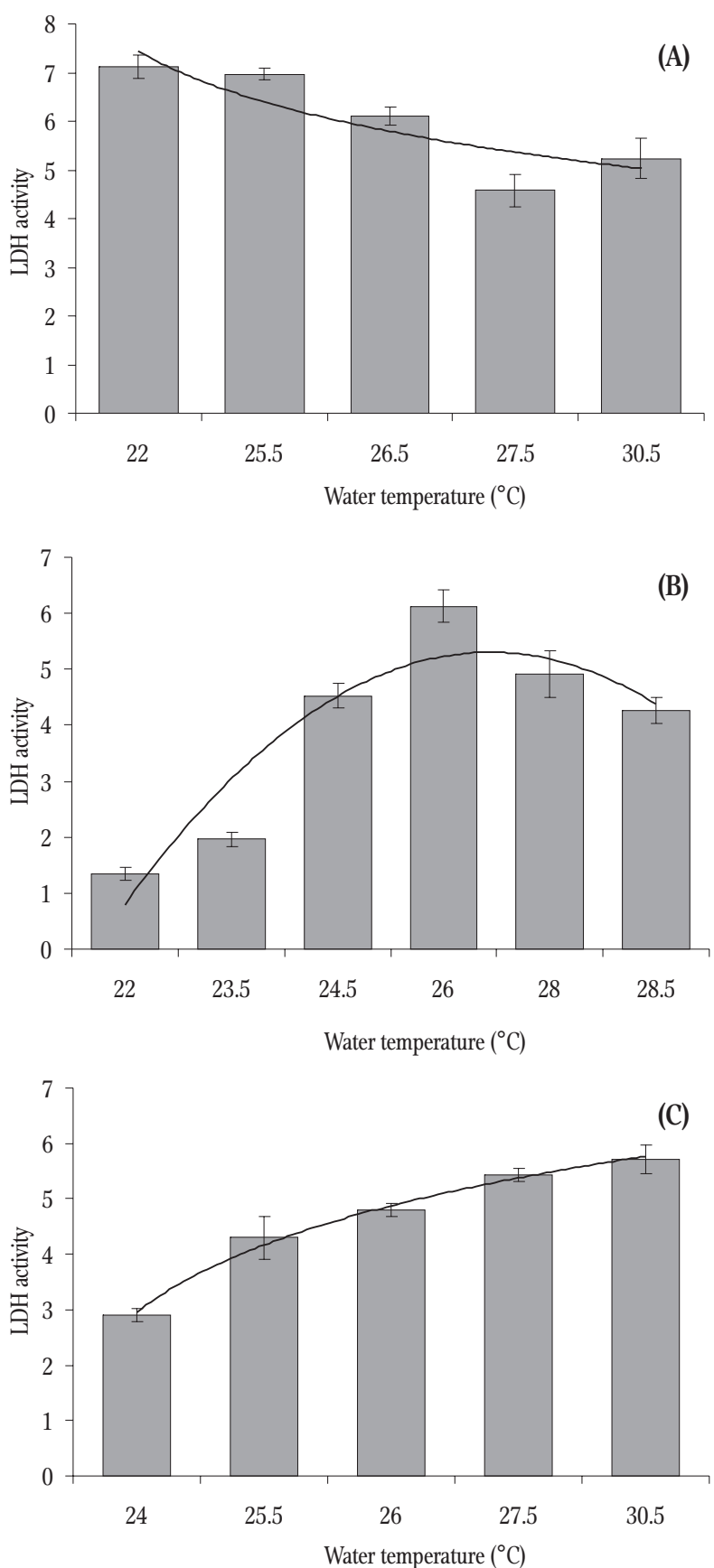

Figure 5. Changes in LDH activity (nmol $\mathrm{min}^{-1} \mathrm{mg}$ of total protein $^{-1}$ ) in carp embryos influenced by water temperature. Data are mean \pm SE, $n=45$.

the water temperature increased. In general, the activity of the enzyme increased significantly compared to the previous stage of development, for example, 5.2 times at a water temperature of $22^{\circ} \mathrm{C}(\mathrm{P}<0.001)$.

\section{Discussion}

The cellular mechanisms of aquatic organism resistance to temperature remain extremely poorly understood, and few works focus on this topic. Given the likely negative impacts of global climate change, studying the specificities of these mechanisms in fish is currently imperative. Reactions to sudden, non-cyclic effects of water temperature have not been studied in the majority of fish species, nor have the values of the tolerable upper temperature limits been determined for the majority of fish species. The consequences of the impact of the environmental temperature factor have not yet been studied in any detail. The activity of key enzymes of energy metabolism in fish makes it possible to assess the intensity and direction of the pathways of aerobic and anaerobic ATP synthesis under the influence of various environmental factors (Churova et al. 2011). Cell membranes can play an important role in adapting to temperature changes. The role of ATPase could be key not only in maintaining the structural integrity of membranes, but also in ensuring their functional status and ion exchange (Kravtsov and Aleksenko 1990, Vinogradov 2000, Zaprudnova 2003).

The study of enzymatic systems at different levels in fish at a sublethal temperature range allows for a re-evaluation of both the adaptive capabilities and physiological and biochemical mechanisms of aquatic animals in the process of temperature adaptation (Korwin-Kossakowski 2008, Konstantinov and Zdanovich 1985, Zdanovich and Pushkar 2001, Saat and Veersalu 1996, Varsamos et al. 2005).

It is widely known at that the vital activity of aquatic organisms is largely regulated by the influence of external factors. Cell membrane ATPases are among the first enzymes to mount a primary response to the impact of environmental factors and mechanisms shaping long-term adaptations (Antonov 1997, Killian and van Meer 2001, Wen et al. 2013). $\mathrm{Na}^{+} / \mathrm{K}^{+}$ATPase is one of the key enzymes necessary for vital cell activity. It provides the optimal intracellular ratio of $\mathrm{Na}^{+}$and $\mathrm{K}^{+}$ions, and the transfer of various metabolites, sugar, and amino acids 
across cell membranes (Boiko et al. 2002, 2004, Kaivarainen et al. 2010).

The current studies showed that the activity of $\mathrm{Na}^{+} / \mathrm{K}^{+}$ATPase in carp embryos decreased significantly with increasing water temperature. This indicated that embryos were significantly isolated from the unfavorable, external environment through decreased ion exchange with it and the transition to anaerobic metabolism in tissues. It was especially important that the dissolved water oxygen content decreased to 2.5-2.8 $\mathrm{mg} \mathrm{l}^{-1}$ under these temperature conditions, and the development of embryos slowed somewhat (Vodianitskiy et al. 2017). In our opinion, this is a manifestation of embryonic compensatory reactions to the increasing impact of temperature and decreases in water oxygen concentrations.

It can be said whether the environmental conditions are optimal or critical in natural water bodies in terms of the direction of changes in the $\mathrm{Na}^{+} / \mathrm{K}^{+}$ ATPase activity and its value during embryonic development. In the current study, the optimal temperature regime for carp development was $22-24^{\circ} \mathrm{C}$, and the optimum temperature range did not change throughout carp embryonic development.

Successful carp embryonic development occurs under both stable oxygen and temperature conditions, and with significant fluctuations in these parameters during the day. However, this changes the growth rates of embryos and their development, which can be accompanied by impaired embryonic cell division that results in decreased embryo viability.

Biological oxidation, which is closely related to providing cells with energy, is based on reactions involving dehydrogenases. Reactions catalyzed by dehydrogenases, as a rule, are inverse; therefore, some of them are involved in reducing biosynthetic processes. Thus, LDH catalyzes the reaction of mutual conversion of lactate into pyruvate. Depending on the direction of the reaction catalyzed by various isoenzymes, the enzyme activity serves as an indicator of the intensity of anaerobic metabolism mainly in muscles, an indicator of gluconeogenesis, or the process of glucose re-synthesis in the liver or the conversion of lactate into pyruvate with its subsequent inclusion in aerobic metabolism. In the Krebs cycle,
SDH catalyzes the reverse oxidation of succinic acid to fumaric acid. Therefore, the activity of dehydrogenases can be used to diagnose the condition of bodies that are diseased or under adverse conditions (Burness et al. 1999, Ahmad and Hasnain 2005, Abrosimova and Abrosimova 2012).

Normal healthy tissue cells meet their energy needs aerobically. A small portion of energy is generated during glycolysis. An increase in LDH activity indicates an increase in glycolysis. A change in the $\mathrm{SDH} / \mathrm{LDH}$ ratio toward an increase in $\mathrm{LDH}$ and a decrease in SDH activity indicates that redox processes are being replaced by anaerobic ones (Kaupp 1987, Yang and Somero 1996, Burness et al. 1999).

An atypical increase in water temperature during fish spawning under natural conditions along with decreased water oxygen content significantly affects LDH activity in embryos, which begins to increase under these conditions. Conversely, the activity of $\mathrm{SDH}$ is significantly reduced. The direction of the energy metabolism in the embryo changes from aerobic to anaerobic when normal temperatures $\left(22-24^{\circ} \mathrm{C}\right)$ are exceeded. Effective fish reproduction becomes impossible with further increases in temperature at spawning grounds when the upper limit of the tolerated temperature is reached.

The analysis of the results of studies of $\mathrm{LDH}$ and $\mathrm{SDH}$ activity indicated that these indicators were highly sensitive to the influence of fluctuations in water temperature and oxygen concentration at spawning grounds. Enzyme activity changed accordingly when dissolved oxygen or water temperature values approached threshold levels. Moreover, LDH activity increased in the early stages of embryo development as water temperature increased. The opposite effect of increased temperature was manifested at a later mobile embryo stage of development. Embryonic energy resources were probably at an extremely low level and were insufficient to maintain anaerobic respiration.

Thus, energy metabolism clearly reacted to changes in environmental conditions throughout carp embryogenesis, and it depended on the embryonic developmental stage. $\mathrm{LDH}$ and SDH activities confirmed that the optimal temperature for the normal carp 
embryo development was $22-24^{\circ} \mathrm{C}$. The current study also confirmed that the carp embryos actively counteracted temperatures up to $26 s ̧ \mathrm{C}$ particularly through glycolysis. At higher temperatures, the activity of all the enzymes studied indicated that the organism was unable to resist subsequent increases.

\section{Summary}

Water temperatures that exceeded the optimum $\left(24-26^{\circ} \mathrm{C}\right)$ and reduced oxygen concentrations (2.6-3.5 $\left.\mathrm{mg} \mathrm{l}^{-1}\right)$ in the predawn hours significantly reduced the activity of $\mathrm{Na}^{+} / \mathrm{K}^{+}$ATPase in carp embryos by $22.8-59.0 \%$, which indicated the inhibition of metabolic processes and transport between the external and internal environments of the embryos.

Carp embryo LDH activity increased (1.7-1.9 times) as water temperature increased and water oxygen concentration decreased indicating that embryos used larger amounts of reserve substances, which indicated the active use of glycolysis to maintain energy balance.

When water temperature and oxygen conditions were unfavorable for embryonic carp development, SDH activity in tissues decreased several times, which indicated the inhibition of aerobic energy supply processes. This could have adversely affected the physiological state of the embryos and significantly reduced larval viability.

Author contributions. O.V. and M.P. designed and performed the experiment; Yu.Kh. and O.Z. analyzed the data, and O.P. wrote the paper.

\section{ORCID iD}

Oleksandr S. Potrokhov iD https://orcid.org/0000-0002-8274-6898

\section{References}

Abrosimova, N.A., Abrosimova, K.S. (2012). Activity of dehydrogenases in the process of development of sympathy in young sturgeon Acipenser ruthenus L). Ecology of animals of the South of Russia: ecology, development, 1, 59-63 (in Russian).
Ahmad, R., Hasnain, A.U. (2005). Ontogenetic changes and developmental adjustments in lactate dehydrogenase isozymes of an obligate air-breathing fish Channa punctatus during deprivation of air access. Comparative Biochemistry and Physiology Part B: Biochemistry and Molecular Biology, 140(2), 271-278.

Anderson, N. (2012). The effects of hypoxia and temperature on developing embryos of the annual killifish Austrofundulus limnaeus. Portland State University, Dissertations and Theses. Paper 888. https://doi.org/10.15$760 /$ etd.888

Antonov, V.F. (1997). Membrannyy transport (Membrane transport). Soros Educational Journal, 6: 4-12 (in Russian).

Asatiani, V.S. (1965). New methods of biochemical photometry. Nauka, Moscow (in Russian).

Boiko N., Celevycz, M., Sanagurski, D. (2002). The heavy metal ion influence on the $\mathrm{Na}+, \mathrm{K}+$-ATPase activity and the dynamic of transmembrane potential of loach embryos. Visnyk of Lviv University. Series: Biology, 29, 25-31 (in Ukraine).

Boiko, N.M., Tselevych, M.V., Sanagurski, D.I. (2004). Activity of membrane $\mathrm{Na}+, \mathrm{K}+$-ATPase of embryos of loach (Misgurnus fossilis L.) under the influence of heavy metal cations. Ukrains'kyi Biokhimichnyi Zhurnal, 76 (2): 59-63 (in Ukraine).

Burness, G.P., Leary, S.C., Hochachka, P.W., Moyes, C.D. (1999). Allometric scaling of RNA, DNA, and enzyme levels: an intraspecific study. American Journal of Physiology-Regulatory, Integrative and Comparative Physiology, 277(4), R1164-R1170.

Churova, M.V., Meshcheryakova, O.V., Nemova, N.N. (2011). Interrelation of activity of enzymes of energy metabolism with growth rates and fish sizes. Scientific notes of Petrozavodsk State University, 153, 7-14 (in Russian).

D’Amico, S., Claverie, P., Collins, T., Georlette, D., Gratia, E., Hoyoux, A., ... Gerday, C. (2002). Molecular basis of cold adaptation. Philosophical Transactions of the Royal Society of London. Series B: Biological Sciences, 357(1423), 917-925.

Dahlhoff, E.P. (2004). Biochemical indicators of stress and metabolism: applications for marine ecological studies. Annual Review of Physiology, 66, 183-207.

Das, T., Pal, A.K., Chakraborty, S.K., Manush, S.M., Dalvi, R.S., Sarma, K., Mukherjee, S.C. (2006). Thermal dependence of embryonic development and hatching rate in Labeo rohita (Hamilton, 1822). Aquaculture, 255(1-4), 536-541.

Eme, J., Mueller, C.A., Manzon, R.G., Somers, C.M., Boreham, D.R., Wilson, J.Y. (2015). Critical windows in embryonic development: Shifting incubation temperatures alter heart rate and oxygen consumption of Lake Whitefish (Coregonus clupeaformis) embryos and hatchlings. Comparative Biochemistry and Physiology Part A: Molecular \& Integrative Physiology, 179, 71-80.

Gracey, A.Y., Lee, T.H., Higashi, R.M., Fan, T. (2011). Hypoxia-induced mobilization of stored triglycerides in the euryoxic goby Gillichthys mirabilis. Journal of Experimental Biology, 214(18), 3005-3012. 
Herzig, A., Winkler, H. (1986). The influence of temperature on the embryonic development of three cyprinid fishes, Abramis brama, Chalcalburnus chalcoides mento and Vimba vimba. Journal of Fish Biology, 28(2), 171-181.

Hochachka, P.W., Somero, G.N. (2002). Biochemical Adaptation: Mechanism and Process in Physiological Evolution. Oxford: Oxford University Press.

Kaupp, S.E. (1987). The ontogenetic development of the metabolic enzymes citrate synthase and lactate dehydrogenase in the swimming muscles of larval and juvenile fishes. $\mathrm{PhD}$ thesis, University of California, San Diego.

Killian, J.A., van Meer, G. (2001). The ‘double lives' of membrane lipids. EMBO reports, 2(2), 91-95.

Konstantinov, A.S., Zdanovich, V.V. (1985). Influence of temperature oscillations on growth and physiological state of carp juveniles. Doklady Akademii Nauk SSSR, 282, 760-764 (in Russian).

Konstantinov, A.S., Zdanovich, V.V. (1986). Some features of fish growth at fluctuating temperature. Voprosy Ikhtiologii, 26(3), 971-977 (in Russian).

Korwin-Kossakowski, M. (2008). The Influence of temperature during the embryonic period on larval growth and development in carp, Cyprinus carpio L., and grass carp, Ctenopharyngodon idella (Val.): Theoretical and practical aspects. Archives of Polish Fisheries, 16, 231-314.

Kravtsov, A.V., Aleksenko, I.R. (1990). Mechanisms of regulation of biomembrane vector enzymes. Naukova Dumka Kiev (in Russian).

Kaivarainen, E.I., Borvinskaya, E.V., Serupin, G.G., Kuklina, M.M., Nemova, N.N. (2010). Role of $\mathrm{Na}+/ \mathrm{K}+-$ ATPase in biochemical mechanisms of adaptation to biotic and abiotic environmental factors. In: Problems of physiology and biochemistry and water organisms. Mat. III Intern. Conf. Petrozavodsk: 100-101 (in Russian).

Love, R.M. (1976). Chemical biology of fish. Food industry, Moscow (in Russian).

Lowry, O.H., Rosebrough, N.J., Farr, A. L., Randall, R.J. (1951). Protein measurement with the Folin phenol reagent. Journal of Biological Chemistry, 193, 265-275.

Menzorova, N.I., Rasskazov, V.A. (2007). Application of different test systems and biochemical indicators for environmental monitoring of the Troitsa Bay, Sea of Japan. Russian Journal of Marine Biology, 33(2), 118-124.

Nilsson, G.E., \& Renshaw, G.M. (2004). Hypoxic survival strategies in two fishes: extreme anoxia tolerance in the North European crucian carp and natural hypoxic preconditioning in a coral-reef shark. Journal of Experimental Biology, 207(18), 3131-3139.

Prohorova, M.I. (1982). Methods of biochemical research (lipid and energy metabolism). Publishing House of Leningrad University Press, Leningrad (in Russian).

Richards, J.G. (2009). Metabolic and molecular responses of fish to hypoxia. In: Fish physiology. Hypoxia: Vol. 27 (Ed.) J. G. Richards, A. P. Farrell, C. J. Brauner, Academic Press: 443-485.
Saat, T., Veersalu, A. (1996). The rate of early development in perch Perca fluviatilis L. and ruffe Gymnocephalus cernuus (L.) at different temperatures. Annales Zoologici Fennici, 33, 693-698.

Schneider, J.C., Copeland, J., Wolgamood, M. (2002). Tolerance of incubating walleye eggs to temperature fluctuation. North American Journal of Aquaculture, 64(1), 75-78.

Sollid, J., Kjernsli, A., De Angelis, P.M., Røhr, A.K., Nilsson, G.E. (2005). Cell proliferation and gill morphology in anoxic crucian carp. American Journal of Physiology-Regulatory, Integrative and Comparative Physiology, 289(4), R1196-R1201.

van der Meer, D.L., van den Thillart, G.E., Witte, F., de Bakker, M.A., Besser, J., Richardson, M.K., ... Bagowski, C.P. (2005). Gene expression profiling of the long-term adaptive response to hypoxia in the gills of adult zebrafish. American Journal of Physiology-Regulatory, Integrative and Comparative Physiology, 289(5), R1512-R1519.

Varsamos, S., Nebel, C., Charmantier, G. (2005). Ontogeny of osmoregulation in postembryonic fish: a review. Comparative Biochemistry and Physiology Part A: Molecular \& Integrative Physiology, 141(4), 401-429.

Via, J.D., van den Thillart, G., Cattani, O., de Zwaan, A. (1994). Influence of long-term hypoxia exposure on the energy metabolism of Solea solea. II. Intermediary metabolism in blood, liver and muscle. Marine Ecology Progress Series, 111, 17-27.

Vinogradov, G.A. (2000). Processes of ion regulation in freshwater fish and invertebrates. Nauka, Moscow (in Russian).

Vodianitskiy, O.M., Potrokhov, O.S., Zinkovskiy, O.G. (2017). Embryonic and early postembryonic development of carp and activity of enzymes of the energy and plastic metabolism under impact of water temperature fluctuations. Hydrobiological Journal, 53(1), 78-86.

Vovk, P.S. (1974). Reactions of embryos and larvae of grass carp to temperature effects. In: Diversity of early ontogenesis in fish (Ed.) V. I. Vladimirov, Naukova Dumka, Kiev: 191-226 (in Russian).

Wen, W., Huang, X., Chen, Q., Feng, L., Wei, L. (2013). Temperature effects on early development and biochemical dynamics of a marine fish, Inimicus japonicus. Journal of Experimental Marine Biology and Ecology, 442, 22-29.

Yang, T.H., Somero, G.N. (1996). Activity of lactate dehydrogenase but not its concentration of messenger RNA increases with body size in barred sand bass, Paralabrax nebulifer (Teleostei). Biological Bulletin, 191(2), 155-158.

Zaprudnova, R.A. (2001). Stress in freshwater fish: issues of ionic regulation. In: Problems of ecology, biology, environmental education, chemistry. Yaroslavl: 248-250 (in Russian).

Zaprudnova, R.A. (2003). Exchange and regulation of cations in freshwater fish under stress. Author. diss. Cand. biol. sciences, Borok (in Russian).

Zdanovich, V.V., Pushkar, V.Y. (2001). The effect of frequent periodic fluctuations in temperature on fish metabolism. Voprosy Ikhtiologii, 41, 129-132 (in Russian). 